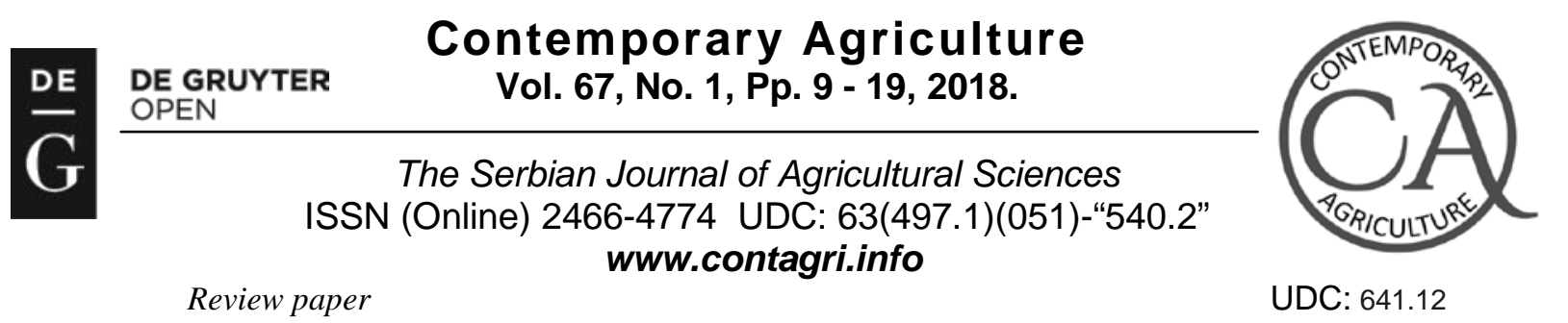

Review paper

DOI: $10.2478 /$ contagri-2018-0002

\title{
COLOR SHADE NETS IMPROVE VEGETABLES QUALITY AT HARVEST AND MAINTAIN QUALITY DURING STORAGE
}

\author{
Zoran S. ILIĆ ${ }^{*}$, Lidija MILENKOVIĆ ${ }^{1}$, Ljubomir ŠUNIĆ ${ }^{1}$, Maja MANOJLOVIĆ ${ }^{2}$
}

\begin{abstract}
Summary: The photoselective, light-dispersive shade nets can be used as an alternative to protect crops from adverse environmental conditions such as; excessive solar radiation, heat and drought stress, wind and hail, birds, flying pests, thus improving crop's production, yield and quality. The physiological parameters discussed in the review include: vegetable growth parameters (leaf area, leaf chlorophyll), tissue structure, fruit ripening, physiological disorders, pest and disease incidence, fruit quality parameters (soluble solids content and titratable acidity), bioactive compounds (antioxidant activity, ascorbic acid, carotenoid and flavonoid contents) and aroma volatile compounds at harvest. Also, it is evident in the reviewed literature that light quality influences the biosynthesis, accumulation and retention of vegetable phytochemicals, as well as the decay development during storage. These new strategies to modulate light quality should be conveyed to vegetable producing farmers, thus allowing them to preserve the freshness and post-harvest quality of vegetables for an extended period of time, and to meet the consumers demand for vegetables with high nutritional value all year round. Research on light manipulation in horticultural systems is necessary for a sustainable and market-oriented open field and greenhouse vegetable production in the future.
\end{abstract}

Key words: light quality; fresh produce; acidity; ascorbic acid; storage life

\section{INTRODUCTION}

The recent rise in global warming across the world has posed severe challenges to crop production. Among others, the challenges include increase in air temperature (AT) and intensity of solar radiation (Meena et al., 2014). Sustained high temperatures $\left(35-40^{\circ} \mathrm{C}\right.$ ) as a result of high solar radiation can also increase the incidence of vegetables abiotic disorders as the climate changes (Ilić et al., 2012), impair cell division, leaf expansion and reproductive development (Flaishman et al., 2015).

The photoselective shade netting technology has gained popularity worldwide over the years, as it has the potential to improve light quality while improving the crop quality at harvest. Manipulation of light quality is currently applied in horticulture via photo-selective netting or films to improve yield, quality and phytochemical components. It is a technology that can be used as an alternative to protect crops from adverse environmental conditions excessive solar radiation (Ilić et al., 2011), heat and drought stress (Meena et al., 2014; Tinyane et al., 2015), wind and hail (Teitel et al., 2008), flying pests (Shahak, 2008), thus improving crop’s production, yield and quality. This technology has the ability to lengthen shelf life of produce, thereby lowering postharvest losses.

Shade nets characterized by different structure, by radiometric and physical properties and mechanical characteristics (Castanello et al., 2008). Modern shade nets are manufactured from woven polypropylene or knitted polyethylene materials with different dimensions of fibres and holes to achieve specific shade levels (Castellano, 2008a; Appling, 2012). The fraction of light that passes through the holes in the shade cloth remains unchanged in its quality, while the light hitting the threads is spectrally modified and scattered on exit (Appling, 2012). The combination of light-scattering and spectral manipulation can modify desirable plant growth characteristics. In addition to light, shade nets may modify environmental variables such as temperatures, wind speed, or relative humidity inside the canopy (Arthurs et al., 2013).

Review paper / Pregledni rad

${ }^{1}$ Zoran Ilić PhD, full professor, University of Priština, Faculty of Agriculture Priština, 38219, Lešak, Serbia

${ }^{1}$ Lidija Milenković $\mathrm{PhD}$, asistance professor, ${ }^{1}$ Ljuborir Šunić $\mathrm{PhD}$, asistance professor, Faculty of Agriculture Priština-Lešak

${ }^{2}$ Maja Manojlović PhD, full professor, University of Novi Sad, Faculty of Agriculture, 21000 Novi Sad, Serbia

*Corresponding author: zoran.ilic63@gmail.com , mob phone +381-638014966 
Photo-selective nets are also used to prolong harvest in excess light (Castellano et al., 2008) by protecting from sunburns and blossom-end rot, and reducing the water use all of which results in higher marketable yields (Moller and Assouline 2007). Color shade nets reduced light intensity by at least $50 \%$ relative to the outside (2000 $\mu \mathrm{mol} \mathrm{m}^{-2}$ $\mathrm{s}^{-1}$ ) during the summer months to levels similar to fall and spring (Ilić et al., 2017b; Fig. 1).

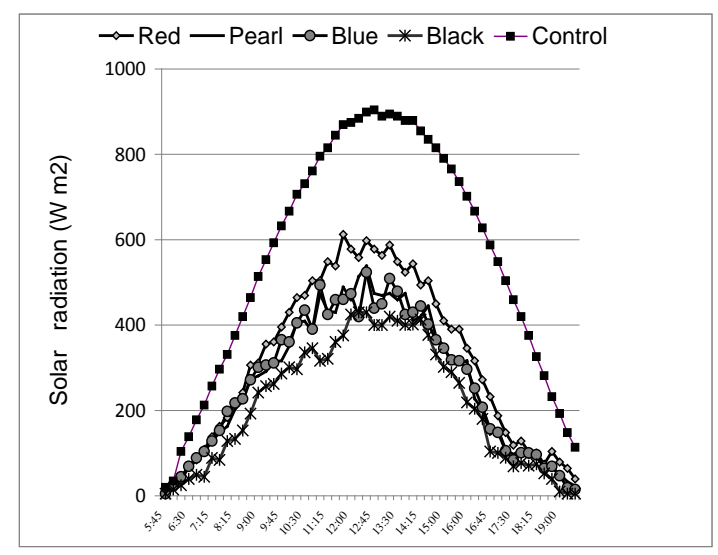

A

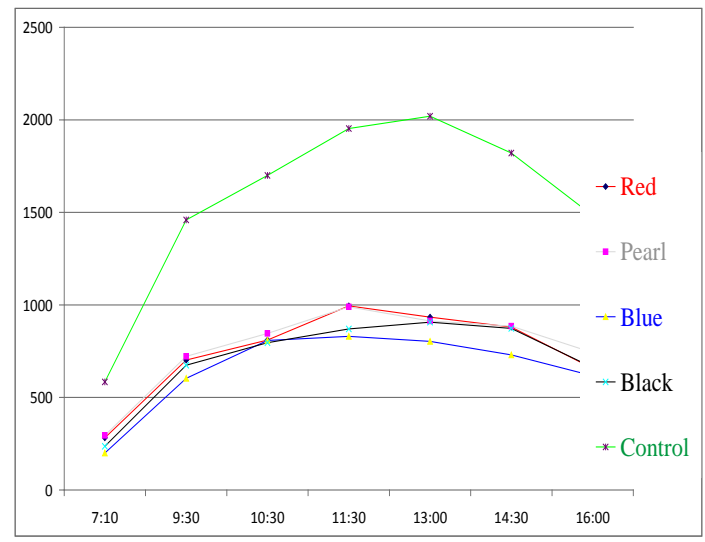

B

Figure 1. A- Solar radiation $\left(\mathrm{W} \mathrm{m}^{-2}\right)$ over lettuce canopy and B- photosynthetically active radiation

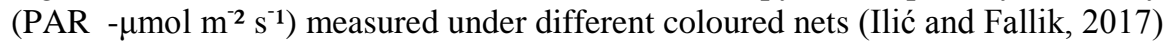

Light modification and micro climate conditions under the pearl photo-selective nets provide better crop yields (Ilić et al., 2011), reduce fruit susceptibility to fungal infection in the field (Goren et al., 2011) and lower susceptibility to decay during post-harvest storage compared to traditional black nets (Stamps, 2009; Fallik et al., 2009; Goren et al., 2011; Shahak, 2014). Spectral manipulation can trigger a wide range of physiological responses, while the efficiency of light-dependent processes has a large impact on pepper (Ilić et al., 2011; 2017; Mashabela et al., 2015; Selahle et al., 2015), tomato (Tinyane et al., 2013; Ilić et al., 2015), lettuce (Ntsoane et al., 2015) and fresh herbs (Buthelezi et al., 2016) production. Nettings have also been shown to influence the retention of sensory quality and phytochemical parameters of vegetables at harvest and postharvest.

The aim of this review is to elucidate the latest information on light quality manipulation by colour shade-nets as shading treatments and on their possible modes of action to control plant development (leaf area index, photosynthetic pigments), fruit maturity, color development, physiological disordes, rot development during production and how to retain overall fruit quality parameters, bioactive compounds and aroma volatiles during postharvest storage.

\section{Leaf area index (LAI)}

Leaf area index (LAI) plays an important role in determining photosynthetic rate/net assimilation rate and yield, the value of which depends on light condition and canopy structure. Lower light intensities increased the stem elongation, leaf blade area and leaf area index. The bell pepper plant leaf area, individual leaf area, dry weight, leaf weight ratio have all been found to increase with increased shade level, whereas the specific leaf weight decreases in this condition (Diaz-Perez, 2013). Bell peppers present leaf and stem morphological and physiological adaptations in response to shade.

Ilic et al. (2017) found that all shade nets significantly increase the leaf area index (LAI), compared to the LAI values obtained from control plants (plastic tunnel). Generally, pepper under plastic tunnels integrated with coloured shade-nets have a higher LAI in comparison to the plant LAI obtained under net house (only coloured nets). Among the coloured nets, pepper plants under black nets produce crop with the lowest LAI value. Leaf area indices ranged from 1.2 in open field crop (control) to maximum LAI values of 2.9 in plants under plastic tunnel cover with pearl nets (Table 1). 
Table 1. Leaf area index (LAI) in sweet pepper as affected by light intensity using colored shade nets

(Ilić et al., 2017a)

\begin{tabular}{cccccc}
\hline Coloured nets & Red & Black & Pearl & Blue & Control \\
\hline Plastic tunnel + colored nets & $2.8 \mathrm{a}$ & $2.6 \mathrm{a}$ & $2.9 \mathrm{a}$ & $2.6 \mathrm{a}$ & $2.0 \mathrm{bd}$ \\
\hline Only colored nets & $2.3 \mathrm{a}$ & $1.3 \mathrm{~b}$ & $2.1 \mathrm{a}$ & $1.7 \mathrm{ab}$ & $1.2 \mathrm{~b}$ 0 \\
\hline
\end{tabular}

Control: $\mathbf{a}$ - plastic tunnel, $\mathbf{0}$ - open field; different letters in the same column indicate statistically significant differences (significance level $P=0.05$ ).

Santana et al. (2012) reported minor differences in LAI value of pepper plants under shading net comparing with plants from open field. Thus, the red screen (40\%) promotes slight increase in the LAI values (1.13-1.15) compared to the field conditions (0.94-1.04). Plants grown in the shade tend to have a larger leaf area because cells expand more under low light intensities in order to receive light for photosynthesis.

Increases in leaf area and reduction in the thickness of the leaf blade under shade conditions are usually meets in environments with low light intensity. Ilić et al. (2017) reported that the spongy parenchyma leaf thickness is higher in control pepper plants from open field and plastic tunnels compared to color nets treatment. Similarly, palisade parenchyma leaf thickness is significantly higher in control plants from open field (123.8 $\mu \mathrm{m})$ and plastic tunnels $(108.2 \mu \mathrm{m})$ compared to other color nets treatments. No significant differences in upper and lower epidermis leaf thickness between control plants and plants from color nets houses have been reported.

\section{Chlorophyll and carotenoids content}

At high light intensity, the degradation rate of chlorophyll content in plant leaves is higher than the synthesis rate; therefore, a lower chlorophyll concentration is observed because of the inhibition of chloroplast formation. Consequently, shade leaves in comparison with sun leaves tend to show higher chlorophyll concentrations per unit of leaf weight (Kosma et al., 2013). Shaded leaves of lettuce generally have larger total chlorophyll (chlorophyll $a$ and chlorophyll $b$ ) content than leaves from open field (control). Leaves of lettuce plants, cultivated under blue and black shade nets have the highest total chlorophyll content in comparison with plants cultivated under other color shade nets (Ilić et al., 2017a). Un-shaded control plants obtained the lowest total chlorophyll (Table 2).

Table 2. Photosynthetic pigments $\left(\mathrm{mg} \mathrm{g}^{-1}\right)$ in the leaves of lettuce plants in response to light intensity using colour shade nets (Ilić et al., 2017b)

\begin{tabular}{|c|c|c|c|c|c|c|c|c|}
\hline $\begin{array}{l}\text { Color } \\
\text { nets }\end{array}$ & $\begin{array}{c}\text { Chloroph } \\
a\end{array}$ & $\begin{array}{c}\text { Chlorop } \\
\mathrm{h} \\
b\end{array}$ & $\begin{array}{c}\text { Chlorop } \\
\text { h } \\
a+b\end{array}$ & $\begin{array}{c}\text { Chlorop } \\
\text { h } \\
\text { a/b }\end{array}$ & Carotenoid & $\begin{array}{c}\text { Total } \\
\text { chl/car }\end{array}$ & $\beta$-carotene & $\begin{array}{c}\text { Carotenoids/ } \\
\beta- \\
\text { carotene }\end{array}$ \\
\hline Pearl & $257.4^{\mathrm{b}}$ & $135.6^{\mathrm{a}}$ & $393.0^{b}$ & $1.90^{\mathrm{b}}$ & $291.8^{\mathrm{a}}$ & $1.35^{b}$ & $50.6^{\mathrm{a}}$ & $5.76^{\mathrm{a}}$ \\
\hline Blue & $352.6^{\mathrm{a}}$ & $98.1^{\mathrm{b}}$ & $450.7^{\mathrm{a}}$ & $3.60^{\mathrm{a}}$ & $149.6^{\mathrm{b}}$ & $3.02^{\mathrm{a}}$ & $48.5^{\mathrm{ab}}$ & $3.08^{b}$ \\
\hline Black & $343.7^{\mathrm{a}}$ & $103.8^{\mathrm{b}}$ & $447.5^{\mathrm{a}}$ & $3.31^{\mathrm{a}}$ & $145.2^{\mathrm{b}}$ & $3.08^{\mathrm{a}}$ & $54.2^{\mathrm{a}}$ & $2.68^{\mathrm{b}}$ \\
\hline Red & $249.8^{b}$ & $70.2^{\mathrm{b}}$ & $320.0^{\mathrm{b}}$ & $3.56^{\mathrm{a}}$ & $104.3^{\mathrm{b}}$ & $3.07^{\mathrm{a}}$ & $36.4^{\mathrm{b}}$ & $2.86^{\mathrm{b}}$ \\
\hline Control & $269.2^{\mathrm{b}}$ & $68.1^{b}$ & $337.3^{b}$ & $3.95^{\mathrm{a}}$ & $91.6^{\mathrm{b}}$ & $2.59^{\mathrm{a}}$ & $44.0^{\mathrm{ab}}$ & $2.08^{\mathrm{b}}$ \\
\hline
\end{tabular}

Control: open field, Different letters in the same column indicate statistically significant differences (sign. level $P=$ 0.05).

Shade-grown leaves harvest lower levels of light, and thus contains more chlorophyll than leaves exposed to direct sun. Although shade-grown leaves are not directly exposed to sunlight, they produce additional chlorophyll to capture diffuse radiation to produce the carbohydrates needed for the plant to grow. That content of chlorophyll $a$ and $b$ increased under low light conditions also supported by the results of Beneragama and Goto (2010).

Chlorophyll content has been reported to decrease after several storage days (Perucka et al., 2013). The reduction in the level of these pigments depends on the species, variety and temperature. When the green color of leafy vegetables is lost (browning, chlorophyll and carotenoids) degradation takes place. A strong positive linear relationship has been described between the chlorophyll content of the leaves and the fruit yield (Ombodi et al., 
2016). Chlorophyll content of pepper fruits grown under pearl net was significantly higher than chlorophyll of fruit grown under the black net (Alkalai-Tuvia et al., 2014).

Carotenoids serve to protect chlorophyll from too much light or the wrong wave lengths thereof, and thus act as a selective filter. Increased temperature and solar radiation during tomato production reduced lycopene and $§$-carotene value, resulting in induction of sunscald (Díaz-Pérez, 2014). Carotenoids content was lowest in plants from open fields and the largest in plants cover by black nets (Ilić et al., 2017).

\section{Tissue structure}

During the hot summer months, cool-season vegetables like lettuce can be grown only under shaded conditions. For lettuce to properly form heads, individual leaves need to be sufficiently large, petioles short, rate of stem elongation slow, and production of the leaves adequately fast. Lettuce heads under shade nets obtained soft, partially open heads with frequent bolting. Results indicate that high temperature tolerance of colour shade applied plants is primarily linked to improved leaves texture.

Table 3. Pepper fruit structural characteristics $(\mu \mathrm{m})$ as affected by coloured shade nets (Ilić et al., 2017a)

\begin{tabular}{cccccc}
\hline Colour nets & Exocarp & Mesocarp & Giant cells & Endocarp & Perikarp \\
\hline Red & $124.87 \mathrm{a}$ & $4467.52 \mathrm{a}$ & $347.13 \mathrm{a}$ & $30.26 \mathrm{a}$ & $4637.10 \mathrm{a}$ \\
Black & $146.04 \mathrm{a}$ & $4373.34 \mathrm{ab}$ & $408.61 \mathrm{a}$ & $26.19 \mathrm{a}$ & $4609.32 \mathrm{ab}$ \\
Pearl & $140.29 \mathrm{a}$ & $3455.58 \mathrm{ab}$ & $393.68 \mathrm{a}$ & $29.14 \mathrm{a}$ & $3649.13 \mathrm{ab}$ \\
Blue & $138.17 \mathrm{a}$ & $3094.85 \mathrm{bc}$ & $329.39 \mathrm{a}$ & $26.82 \mathrm{a}$ & $3237.60 \mathrm{ab}$ \\
Control & $124.68 \mathrm{a}$ & $2972.91 \mathrm{ca}$ & $389.67 \mathrm{a}$ & $23.42 \mathrm{a}$ & $3116.19 \mathrm{ba}$ \\
\hline
\end{tabular}

Different letters in the same column indicate statistically significant differences (significance level $P=0.05$ ).

Under color nets at optimal growing conditions, plants provided fruits with thicker pericarp, firmness and better tolerance to transport and storage. Pericarp thickness (exocarp, mesocarp and endocarp) is significantly higher in plants cover by pearl and red nets compared to open field tomato (Ilić et al., 2015). Pericarp fruit thickness is significantly higher in plants from plastic tunnels covered by color nets compared to pericarp fruit thickness in plants from nets-house and open field. Pericarp fruit thickness is significantly higher in the pepper plants from red netshouse compared to other treatments and control (Ilić et al., 2017a, Tab. 3).

Therefore, the mechanical properties of pepper tissues were determined in this exploration can be used to create optimal growing conditions to achieve fruits with thicker pericarp, firmness and longer postharvest life (Ilić et al., 2017a). Decreases in fruit dry weight percent with shade level indicate that fruit had reduced specific fruit weight (fruit dry weight per unit fruit surface area) or a thinner pericarp or that fruit may have undergone changes in cell structure or cell size under shade.

\section{Physiological disorders}

Intensive light and high temperatures can be detrimental to lettuce, resulting in reduced head yield and increased incidences of leaf physiological disorders such as rib discoloration, tip burn, bolting and bitterness (Ilić et al., 2017b). 
Table 4. Effects of shading on the physiological disorders, texture and taste of lettuce (Ilić et al., 2017b)

\begin{tabular}{lcccccc}
\hline $\begin{array}{l}\text { Color } \\
\text { nets }\end{array}$ & $\begin{array}{c}\text { Rib } \\
\text { discoloration }\end{array}$ & $\begin{array}{c}\text { Tip } \\
\text { burn }\end{array}$ & $\begin{array}{c}\text { Bolting } \\
(1-5 \text { scale })\end{array}$ & $\begin{array}{c}\text { Bitterness } \\
(1-5 \text { scale })\end{array}$ & Texture & Head shape \\
\hline Pearl & 1.0 & 1 & 3.0 & 1.5 & 3 & 4 \\
Blue & 1.0 & 1 & 2.0 & 1.5 & 3.5 & 4 \\
Black & 1.0 & 1 & 2.0 & 1.5 & 3.5 & 3 \\
Red & 1.0 & 1 & 3.0 & 1.5 & 3 & 4 \\
Control & 3.0 & 3 & 1.5 & 3.0 & 1 & 1 \\
\hline
\end{tabular}

Rib discoloration: 1- no rib discoloration; 3-moderate rib discoloration; 5- severe rib discoloration

Tip burn: 1- no tip burn; 3-moderate tip burn; 5-high

Bolting: 1-no bolting, 2-initial elongation, 3-bud appearance, 4-flower stalk development, 5-full flowering

Bitterness: 1-no bitterness, 2-slightly bitter, 3-moderately bitter, 4-bitter, 5-very bitter.

Texture: 1- hard crisp, 2-crunchy, 3-soft-buttery, 4-soft tender

Head shape: 1-very open, 2-open, 3-partially open, 4-closed, 5-very closed

Rib discoloration in lettuce begins with abrowning of the midribs of leaves inside the head as it nears commercial maturity. Shaded lettuce plants generally have smaller percent of rib discoloration than control lettuce plant from open field (Table 4).

Beneficial effects (increased marketable yield and reduced incidence of sunscald) of shading are associated with a reduction of light, air and soil temperature under this conditions resulting in alleviation of heat stress in the plants. High temperatures can be detrimental to bell pepper, resulting in reduced fruit yield and increased incidence of fruit disorders such as sunscald and blossom-end rot. Sunscald was eliminated under shading while pepper cracking, blossom end rot and pericarp lignification were reduced to about 50\% compared to open field conditions (Ilic et al., 2017a). Cracks are due to strong variation in water content likely due to increased leaf transpiration followed by strong water influx. Fruit cracking not only reduces fruit appeal and marketing, but can also increase fruit susceptibility to decay and shorten shelf life. Shading reduced the appearance of pepper cracking and eliminated sunscald on pepper fruits and accordingly, increased the marketable pepper production by about $25 \%$ compared to non-shading conditions (Table 5).

Table 5. Effects of shading on the percentage of physiological disorders of sweet pepper fruits (Ilić et al., 2017a)

\begin{tabular}{ccccccc}
\hline $\begin{array}{c}\text { Coloure } \\
\mathrm{d} \text { nets }\end{array}$ & $\begin{array}{c}\text { Marketabl } \\
\mathrm{e} \\
\text { fruit }\end{array}$ & $\begin{array}{c}\text { Blossom } \\
\text { and root }\end{array}$ & Cracking & $\begin{array}{c}\text { Irregular } \\
\text { shape }\end{array}$ & $\begin{array}{c}\text { Pericarp } \\
\text { lignification }\end{array}$ & $\begin{array}{c}\text { Sun } \\
\text { scald }\end{array}$ \\
\hline Red & $88 \mathrm{a}$ & $5 \mathrm{bc}$ & $1 \mathrm{c}$ & $4 \mathrm{c}$ & $2 \mathrm{bc}$ & - \\
Black & $83 \mathrm{~b}$ & $6 \mathrm{~b}$ & $3 \mathrm{ab}$ & $6 \mathrm{~b}$ & $3 \mathrm{~b}$ & - \\
Pearl & $89 \mathrm{a}$ & $4 \mathrm{c}$ & $1 \mathrm{c}$ & $5 \mathrm{bc}$ & $1 \mathrm{c}$ & - \\
Blue & $83 \mathrm{~b}$ & $6 \mathrm{~b}$ & $2 \mathrm{~b}$ & $6 \mathrm{~b}$ & $3 \mathrm{~b}$ & - \\
Control & $68 \mathrm{c}$ & $8 \mathrm{a}$ & $4 \mathrm{a}$ & $9 \mathrm{a}$ & $5 \mathrm{a}$ & 6 \\
\hline
\end{tabular}

Different letters in the same column indicate statistically significant differences (significance level $P=0.05$ ).

Bell pepper yellow fruit cultivars displayed greater incidence of sunscald than red fruit cultivars. This could be attributed to a likely increased concentration of carotenoids in red fruit cultivars. Carotenoids protect leaves and fruit tissues from photo-oxidative processes associated with sunscald disorder. Several studies have demonstrated improvement in fruit quality and an increase in commercial fruit production due to the use of coloured shading screens (Rajapakse and Shahak, 2007; Stamps, 2009; Ilić et al., 2012; Ilić et al., 2015). All shading nets have been shown to have a protective effect against sunburn compared with the unshaded control pepper plants (Ambrózy et al., 2016). Losses due to sunscald and rotting are estimated to be greater than $35 \%$ under field conditions, while in screen-houses reduce these losses to less than 5\% (Santana et al., 2012). Cracking occurs when there is a rapid influx of water solutes into the fruit at the same time that other factors interact to reduce the strenght and elasticity of the fruit skin. Factors thought to promote this problem include irregular watering, high temeratures and high irradiance 
(Gent, 2008), excessive growth rates, hight differentials between day and night temperature, high humidity and poor calcium nutrition.

Exposure of fruit to sunlight could change the water potential of the fruit directly and cause the skin to crack as a result of heating of the fruit surface. Field-grown fruit exposed to sunlight had more cracks than shaded fruit (Ilić et al., 2012). Fruit cracking not only reduces fruit appeal and marketing, but can also increase the fruit's susceptibility to decay and shorten its shelf life. Fruit surfaces affected by sunscald (sunburn) and cracking are followed by infection with microbes such as Alternaria (Ilić et al., 2012) and Cladosporium rot (Fernández-Trujillo et al., 2013).

\section{Fruit ripening}

High temperature in conjunction with high irradiance also contributed to blotchy or uneven ripening. The spectrum of transmitted light influenced fruit growth by affecting cell proliferation and ripening, and thereby changed the sensory perceptions of fruit appearance, taste, and texture. Ripening of fruits is associated with the biosynthesis of carotenoid and loss of chlorophyll pigments. The findings of Mashabela et al. (2015) revealed that pearl photo-selective nets have higher transmittance of B/FR and R/FR ratios. Exposure of green peppers to higher $\mathrm{R} / \mathrm{FR}$ photon ratios during growth probably could have played a role in suppressing the conversion of biologically active phytochrome, which reduced the expression of genes involved in ripening-related changes including color, biosynthesis of $\beta$-carotene and lycopene.

Light quality and different wave lengths were reported to affect fruit color and maturation in different vegetable plants (Lopez et al., 2007). Exposure of fruits to higher photosynthetically active radiation (PAR) inside the nets and higher fruit surface temperatures under the black nets (Mashabela et al., 2015; Tinyane et al., 2013) during production affected ripening related colour changes in tomatoes and sweet peppers after postharvest storage. Under yellow net, significantly more scattered red light penetrates into the plant and fruit which in turn inhibits fruit ripening and/or, indirectly, induces resistance against Alternaria alternata infection after harvest. Ripening inhibition can be associated with less fruit susceptibility to decay (Barkai-Golan, 2001).

\section{Pest and desease}

Photo-selective filtration of sunlight is reported also to affect plant pests and diseases (Shahak et al., 2008). Therefore, crops grown under these shade nets could potentially be at a higher or lower risk for pest infestation. Although the holes of the shade nets might be large enough to allow free pass of aphids, whiteflies and thrips, these pests respond differently to different photo-selective shade nets (Makled et al., 2012). Yellow or blue coloured nets are known to attract whiteflies and thrips, respectively (Ben-Yakir et al., 2012). This technology is compatible with other methods of plant protection and can be included in integrated pest management programs for pepper and tomato crops.
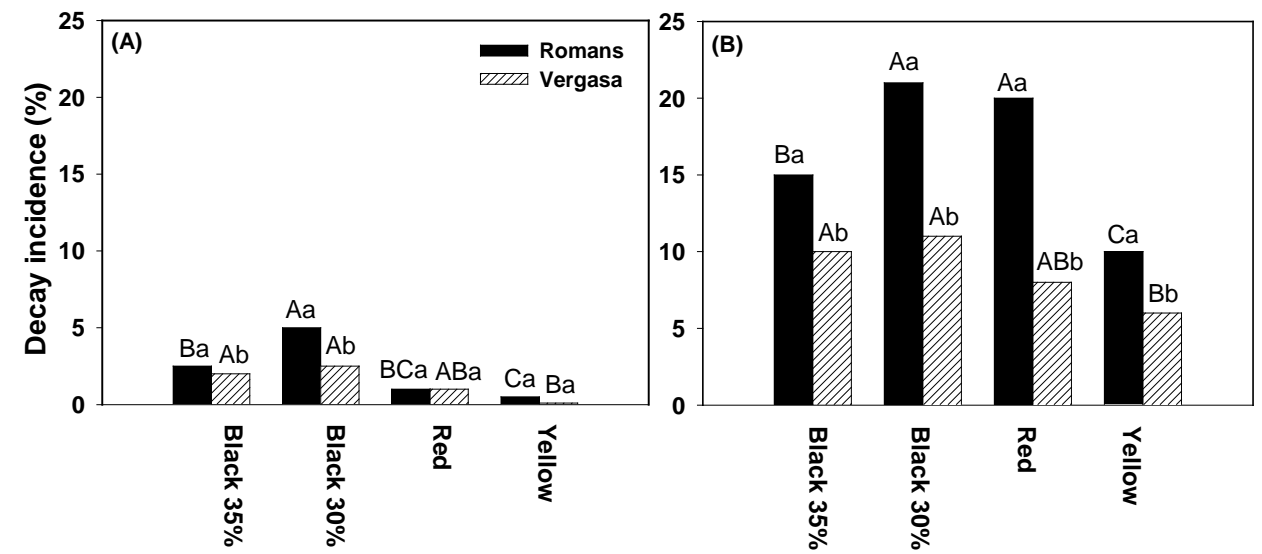

Figure 3. The influence of coloured shade nets on decay incidence of calyx (A) and fruit (B) of cv. 'Romans' and cv. 'Vergasa', after 14 days at $7^{\circ} \mathrm{C}$ plus 3 days at $20^{\circ} \mathrm{C}$ (Fallik et al., 2009)

Different upper-case letters represent significant differences at 5\% between the various nets within the cultivars, and lower-case different letters represent significant differences at $5 \%$ between the cultivars 
Fruits of pepper grown and harvested under yellow shade net, had a significantly lower decay incidence on fruit calyx (Fig. 3A) and fruit pericarp (Fig. 3B), compared to fruits which were harvested under the two black shade nets (Fallik et al., 2009). Fruits which were harvested under 30\% black shade net had the higher decay incidence. The cultivar 'Romans' was found to be more susceptible to decay in the field and decay development during storage and shelf life than cv. 'Vergasa' (Fig. 3). The main decay-causing-agent isolated from decayed pericarp and calyx was Botrytis cinerea.

Photoselective shade nets (yellow and pearl) were found to distinctly reduce pest-borne viral diseases, as well as the occurrence of fungal diseases, in both pre- and post-harvest of sweet pepper fruits (Shahak, 2014). The improved quality was due to low inoculum level of Alternaria spp. in the field, and inhibition of fungal sporulation. In addition, the shade net slowed fruit ripening (Barkai-Golan, 2001) during its growth as shown by external color, which could reduce fruit susceptibility to fungal infection in the field (Goren et al., 2011).

Goren and co-authors (2011) also reported that photo-selective pearl and yellow nets significantly maintained better pepper fruit quality after prolonged storage of 16 days at $7^{\circ} \mathrm{C}$ and shelf life of three days at $20^{\circ} \mathrm{C}$, mainly by reducing decay incidence, compared to commercial black and red nets. Kong et al. (2013) reported that red pepper, which was grown under pearl shade net, had significantly prolonged storage and shelf life, compared with the same pepper grown under the black net. They concluded that the lower decay incidence under the pearl net was due to the scattered light spectrum and the high ratio between the red/far red and blue/UV under the pearl net. The light fragment alteration reduced the inoculum level of Alternaria spp. in the field, inhibited fungal sporulation and inhibited fruit ripening based on skin color development, which has probably led to significant reduction in decay development after harvest, while maintaining the fruit quality (Goren et al., 2011).

\section{Nutritional levels \\ Sugar and acid}

Light quality and different wave lengths affect fruit soluble solids concentration (SSC). Under the black net, the blue light transmittance is significantly higher than under the other nets, whereas under the red nets the red light transmittance was higher and thus one would expect a higher production of photosynthates resulting in an increase of TSS\%. All tomato cultivars grown under black nets had the highest TSS. Fruits from pearl and yellow nets showed moderate SSC/TA ratios after postharvest storage (Tyniane, 2013).

Titratable acidity (TA) in tomato fruits is used along with total soluble sugar (TSS) content ( ${ }^{\circ}$ Brix) as an indicator of maturity (Gonzalez-Cebrino et al., 2011). Among the cultivars, 'Irit' showed significantly higher TA than the other two cultivars and the black nets gave higher TA in all fruits, which shows that the cooler temperatures (under black nets) favoured the accumulation of acids than the higher temperatures (yellow nets) (Aldrich et al., 2010). Different observations were reported regarding the shading effect and TA in tomato fruit. According to ElGizaway et al. (1992), increasing shading levels from 35\% to 63\% increased the TA in tomato fruit while Riga et al. (2008) reported that shading tomato plants by $50 \%$ did not affect the concentration of titratable acidity. The TA content of pepper fruits increased under black nets may be associated with fruit senescence (Fernandez-Trujillo et al., 2009). The SSC was reported to increase with fruit ripening as a result of greater degradation of the polysaccharides and accumulation of sugars (Molinari et al., 1999). The TSS/TA ratio was higher in lettuce produced under the yellow and pearl nets. On the contrary, the TSS/TA was lower in lettuce produced under the red and black nets (Nsoante, 2015).

\section{Carotenoids}

The light quantity (PAR) can affect the $\beta$-carotene accumulation. $\beta$-carotene is the most important carotenoid with provitamin A activity (Gautier et al., 2005). Gautier et al. (2005) stated that the $\beta$-carotene degradation increases from $35{ }^{\circ} \mathrm{C}$ to $40{ }^{\circ} \mathrm{C}$. Although the temperature for $\beta$-carotene biosynthesis was favourable under the all nets where the production was carried out in this study $\left(25-26^{\circ} \mathrm{C}\right)$, the leaf surface temperature could have been higher under the black nets due the higher FR in the light spectrum. The biosynthesis of lycopene is affected by environmental conditions such as air temperature and sunlight (Dumas et al., 2003). Exposure of tomato fruits to excessive sunlight was reported to inhibit the synthesis of lycopene (Brandt et al., 2006). Optimal temperature for lycopene biosynthesis was around $22-260 \mathrm{C}$. Temperatures above $30-35^{\circ} \mathrm{C}$ and excessive solar radiation have been reported to inhibit lycopene biosynthesis (Rosello et al., 2011) in tomato fruits and stimulate the oxidation of lycopene to $\beta$-carotene (Dumas et al., 2003).

Higher surface fruit temperature obtained under pearl net affected the lycopene content in tomatoes. Tomatoes covered by red net showed higher lycopene contents than tomatoes grown under the pearl net (Tinyane et al., 2013). 
Similar observations were reported by Lopez et al., (2007) and Ilić et al., (2012). The observed differences between the lycopene content in tomatoes under the red and pearl nets could be due to the stimulation of lycopene accumulation in tomatoes under the red net due to the slight variation in red light as explained by Ilić et al., (2012) that lycopene synthesis is mediated by phytochromes. The lycopene contents of tomatoes in study by Tinyane et al., (2013) were lower than those reported for newly bred tomatoes reported by Gupta et al., (2011) and cv. Vedeta (Ilić et al. 2012). Storage temperature has a distinct influence on the phytochemicals present during the ripening stage of the product. For example, carotenoid changes occurring during storage depend on the initial physiological stage of vegetables, that is, there is an increase in carotenoid content with continuing maturation or a decrease with senescence and these changes can be promoted or suppressed by temperature (Schreiner, 2006).

\section{Antioxidant activity}

The accumulation of antioxidant compounds during the production of the vegetables depends on many factors such as temperature, light quantity and quality, type of varieties or cultivars, growing season and metabolic factors. Environmental conditions such as higher temperatures and a decrease in plant growth can enhance the antioxidant scavenging activity and overproduction of oxygen reactive species (Miller, 2010).

Spectral quality control under the photo-selective red and pearl nets retaining antioxidant activity after postharvest storage. Increased antioxidant levels, which are induced by the light environment manipulation by the pearl netting, are speculated to be involved in improving the postharvest fruit quality maintenance (Kong et al., 2013). Pepper fruits produced under pearl nets show higher ascorbic acid content and antioxidant scavenging activity after postharvest storage (Alkalai-Tuvia et al., 2014).

Results by Mashabela and coworkers (2015) show the impact of modified light quality on the bioactive compounds of green sweet pepper during postharvest storage. The pearl nets were reported to increasing the antioxidant activity and ascorbic acid content in red sweet peppers (Kong et al., 2013). Antioxidant activity indicated a preference for red pepper fruits after storage from plants grown under pearl nets (Selahle et al., 2015). Antioxidant activity was higher in fresh herbs grown under the yellow and red nets after postharvest storage. Also, no significant differences were noted in leaves from the plants grown under the different nets with respect to antioxidant content after postharvest storage (Buthelezi et al., 2016).

Our observation confirms that the antioxidant scavenging activity of vegetables during post-harvest storage also depends on the genotype, quality of the light, PAR and temperature during cultivation.

\section{Flavonoid content}

Sunlight radiation and its spectral composition regulate many physiological responses in plants, including flavonoid biosynthesis. The influence of UV radiation on the modification of flavonoid composition is well known and light intensity or quantity (PAR) was also reported to favour the production of flavonoid (quercetin), Agati et al. (2013). The FR light $(730 \mathrm{~nm})$ mediates the conversion of biologically active phytochrome (Pfr) to an inactive phytochrome (Pr) form (Favory et al., 2009).

Table 6. Total extractive matter (TEM), total phenols content (TPC), total flavonoids content (TFC) and EC 50 values of lettuce extracts (Ilić et al, 2017b)

\begin{tabular}{lcccc}
\hline & $\begin{array}{c}\text { TEM } \\
\text { g 100g }\end{array}$ & $\begin{array}{c}\text { TPC } \\
\text { mg GAE g }^{-1} \text { d.m. }\end{array}$ & $\begin{array}{c}\text { TFC } \\
\text { mg RE g }^{-1} \text { d.m. }\end{array}$ & $\begin{array}{c}\mathrm{EC}_{50} \\
\mathrm{mg} \mathrm{mL}^{-1}\end{array}$ \\
\hline Pearl & $2.378^{\mathrm{b}}$ & $30.78^{\mathrm{a}}$ & $14.28^{\mathrm{a}}$ & $0.202^{\mathrm{b}}$ \\
Blue & $2.660^{\mathrm{ba}}$ & $22.53^{\mathrm{b}}$ & $4.40^{\mathrm{b}}$ & $0.247^{\mathrm{a}}$ \\
Black & $2.660^{\mathrm{ba}}$ & $21.49^{\mathrm{b}}$ & $7.93^{\mathrm{b}}$ & $0.263^{\mathrm{a}}$ \\
Red & $3.040^{\mathrm{a}}$ & $18.40^{\mathrm{b}}$ & $8.87^{\mathrm{b}}$ & $0.259^{\mathrm{a}}$ \\
Control & $2.945^{\mathrm{a}}$ & $25.41^{\mathrm{b}}$ & $6.28^{\mathrm{b}}$ & $0.231^{\mathrm{ab}}$ \\
\hline
\end{tabular}

g $100 \mathrm{~g}^{-1}$ f.m. - gram TEM per 100 grams of fresh plant material mg GAE $\mathrm{g}^{-1}$ d.m. - milligram of gallic acid equivalents per gram of dry matter

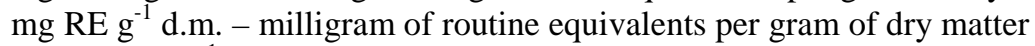

$\mathrm{EC}_{50}$, $\mathrm{mg} \mathrm{mL}^{-1}$ - concentration of the extract is necessary to neutralize $50 \%$ of the initial concentration of DPPH radicals 
Lettuce from the open field production was characterized by high content of total phenols (25.41 mg GAE $\mathrm{g}^{-1}$ d.m.). The total phenol contents in lettuce grown under blue, black and red shade nets were somewhat, but not significantly lower than in control plants. However, total flavonoids content was the lowest in control plants (6.28 $\mathrm{mg} \mathrm{g}^{-1} \mathrm{dm}$ ) while under blue, black and red nets slightly higher contents of total flavonoids were recorded. The highest content of total phenols (30.78 $\mathrm{mg} \mathrm{GAE} \mathrm{g}^{-1} \mathrm{~d} . \mathrm{m}$.) and flavonoids (14.28 $\mathrm{mg} \mathrm{RE} \mathrm{g}^{-1} \mathrm{~d} . \mathrm{m}$.), which was statistically significant different from open field production and other color shade nets, was recorded in the leaves of lettuce cultivated under pearl shade nets (Table 6).

\section{CONCLUSION}

As evident from published literature, shading is one of the methods for recommendation for controlling vegetable plant development and improving productivity and quality before and after harvest. During production, the light quality under the photo-selective shade nets exerts a positive effect on the quality parameters and the phytochemical contents of fresh vegetables. This literature review has presented data regarding vegetable production, photoselective netting technology, sensory quality and bioactive compouds at harvest and postharvest, as well as biotic and abiotic factors that severely affect the quality of vegetables at harvest and after storage. This technology has the ability to extend the shelf life of produce, thereby lowering postharvest losses. Overall, photo-selective shade seem to be a cost-effective approach for manipulating crop microclimate properties that regulate not only yield, but also the retail/eating quality as well as functional or bioactive properties that are associated with human health. The furture research trend like molecular studies relating to light quality is necessary for a sustainable and market-oriented open field and greenhouse vegetable production.

\section{Acknowledgements}

This study, which was part of the TR-31027 project, was financially supported by the Ministry of Science and Technological Development, Republic of Serbia.

\section{REFERENCES}

AGATI, G., BRUNETTI, C., FERDINANDO, M.D., FERRINI, F., POLLASTRI, S., TATTINI, M.: Functional roles of flavonoids in photo protection: new evidence, lessons from the past. Plant Physiology and Biochemistry, 72: 35-45, 2013

ALDRICH, H.T., SALANDANAN, K., KENDALL, P., BUNNING, M., STONAKER, F., OKTAY, K., STUSHNOFF, C.: Cultivar choice provides options for local production of organic and conventionally produced tomatoes with higher quality and antioxidant content. Journal of Science Food and Agriculture, 90: 2548-2555, 2010

ALKALAI-TUVIA, S., GOREN, A., PERZELAN, Y., WEINBERG, T., FALLIK, E.: The influence of colored shade nets on pepper quality after harvest - a possible mode-of-action. Agriculture and Foresttry, 60: 7-18, 2014

AMBRÓZY, Z.S., DAOOD, H., NAGY, Z.S., DARÁZSI, LEDÓ, H., HELYES, L.: Effect of net shading technology and harvest times on yield and fruit quality of sweet pepper. Applied Ecology and Environment Research, 14: 99-109, 2016

APPLING, S.M., Colored shade cloth affects the growth of basil, cilantro, and parsley. M.S.c. thesis, Blacksburg, Virginia Polytechnic Institute and State University. 2012

ARTHURS, S.P., STAMPS, R.H., GIGLIA, F.F.: Environmental modification inside photo-selective shade houses. Horticulturae Science, 48(8): 975-979, 2013

BARKAI-GOLAN, R.: Postharvest diseases of fruits and vegetables: Development and Control. (1 $1^{\text {st }}$ ed.) Elsevier Science BV, Amsterdam, The Netherlands. 2001

BEN-YAKIR, D., ANTIGNUS, Y., OFFIR, Y., SHAHAK, Y.: Colored shading nets impede insect invasion and decrease the incidences of insect-transmitted viral diseases in vegetable crops. Entomologia Experimentalis et Applicata, 144: 249-257, 2012

BENERAGAMA, C.K., GOTO, K.: Chlorophyll $a: b$ ratio increases under low-light in 'shade-tolerant' Euglena gracilis. Tropical Agricultural Research, 22: 12-25, 2010

BRANDT, S., PÉK, Z., BARNA, E., LUGASI, A., HELYES, L.: Lycopene content and colour of ripening tomatoes as affected by environmental conditions. Journal of the Science of Food and Agriculture, 86: 568-572, 2006

BUTHELEZI, M.N.D., SOUNDY, P., JIFON, J., SIVAKUMAR, D.: Spectral quality of photo-selective nets improves phytochemicals and aroma volatiles in coriander leaves (Coriandrum sativum L.) after postharvest storage. Journal of Photochemistry and Photobiology B: Biology, 161: 328-334, 2016

CASTELlANO, S., SCARASCIA MUGNOZZA, G., RUSSO, G., BRIASSOULIS, D., MISTRIONIS, A., HEMMING, S., WAAIJENBERG, D.: Plastic nets in Agriculture: A General review of types and applications. Applied Engineering in Agriculture, 24: 799-808, 2008 
DÍAZ-PÉREZ, J.C.: Bell pepper (Capsicum annuum L.) crop as affected by shade level: Microenvironment, plant growth, leaf gas exchange, and leaf mineral nutrient concentration. HortScience, 48: 175-182, 2013

DÍAZ-PÉREZ, J.C.: Bell pepper (Capsicum annuum L.) crop as affected by shade level: fruit yield, quality, and postharvest attributes, and incidence of phytophthora blight (caused by Phytophthora capsici Leon.). HortScience, 49: 891-900, 2014

DUMAS, Y., DADOMO, M., DI LUCCA, G., GROLIER, P.: Effects of environmental factors and agricultural techniques on antioxidant content of tomatoes. J. Sci. Food Agric. 83, 369-382, 2003

EL-GIZAWY, A.M., ABDALLAH, M.M.F., GOMAA, H.M., MOHAMED, S.S.: Effect of different shading levels on tomato plants 2. Yield and fruit quality. Acta Horticulturae, 323: 349-354, 1992

GAUTIER, H., ROCCI, A., BURET, M., GRASSELLY, D., CAUSSE, M.: Fruit load or fruit position alters response to temperature and subsequently cherry tomato quality. Journal of the Science Food and Agriculturae, 85:1009-1016, 2005

GENT, M.P.N.: Density and duration of shade affect water and nutrient use in greenhouse tomato. J. Amer. Soc. Horticulturae Science, 133: 619-627, 2008

GOREN, A., ALKALAI-TUVIA, S., PERZELAN, Y., AHARON, Z., FALLIK, E.: Photoselective shade nets reduce postharvest decay development in pepper fruits. Advances in Horticultural Science, 25: 26-31, 2011

GONZALEZ-CEBRINO, F., LOZANO, M., AYUSO, M.C., BERNALTE, M.J., VIDAL-ARAGON, M.C., GONZALEZGOMEZ, D.: Characterization of traditional tomato varieties grown in organic conditions. Spanish Jouranl of Agricultural Research, 9: 444-452, 2011

GUPTA, A., KAWATRA, A., SEHGAL, S.: Physical-chemical properties and nutritional evaluation of newly developed tomato genotypes. African Journal of Food Science and Technology, 2: 167-172, 2011.

FALLIK, E., ALKALAI-TUVIA, S., PARSELAN, Y., AHARON, Z., ELMANN, A., OFFIR, Y., MATAN, E., YEHEZKEL, H., RATNER, K., ZUR, N., SHAHAK, Y.: Can colored shade nets maintain sweet pepper quality during storage and marketing? Acta Hortic. 830, 37-44, 2009

FAVORY, J.J., STEE, A., GRUBER, H., RIZZINI, L., ORAVEEZ, A., FUNK, M.: Interaction of COPI and UVR regulates UVB-induced photomorphogenesis and stress acclimation in Arabidopis. EMBO Journal, 28: 591-601, 2009

FERNANDEZ-TRUJILLO, J.P., SERRANO, J.M., MARTINEZ, J.A.: Quality of red sweet pepper fruit treated with 1-MCP during a simulated post-harvest handling chain. Food Science and Technology International, 15: 23-30, 2009

FERNÁNDEZ-TRUJILLO, J.P., LESTER, G. E., DOS-SANTOS, N., MARTÍNEZ, J. A., ESTEVA, J., JIFON, J. L., VARÓ, P.: Pre- and postharvest muskmelon fruit cracking: Causes and potential remedies. Hort Technolology. 23(3): 266-275, 2013

FLAISHMAN, M.A., PELES, Y., DAHAN, Y., MILO-COCHAVI, S., FRIEMAN, A., NAOR, A.: Differential response of cellcycle and cell-expansion regulators to heat stress in apple (Malus domestics) fruitlets. Plant Science, 233: 82-89, 2015

ILIĆ, Z., MILENKOVIC, L., DUROVKA, M., KAPOULAS, N.: The effect of color shade nets on the greenhouse climate and pepper yield. In: Sym. Proceed. $46^{\text {th }}$ Croation and $6^{\text {th }}$ Inter Sym Agric. Opatija, pp. 529-533, 2011

ILIĆ, Z.S., MILENKOVIĆ, L., STANOJEVIĆ, L., CVETKOVIĆ, D., FALLIK, E.: Effects of the modification of light intensity by color shade nets on yield and quality of tomato fruits. Scientia Horticulturae, 139, 90-95, 2012

ILIĆ, S.Z., MILENKOVIĆ, L.: The influence of photoselective shade nets on quality of tomatoes grown under a plastic tunnels and field conditions. In: Book of Proceed. The $4^{\text {th }}$ Joint UNS - PSU Inter. Conf. BioScience. Biotechnology and Biodivesity. Novi Sad, pp. 25-34, 2012

ILIĆ, S.Z., MILENKOVIĆ, L., ŠUNIĆ, L., FALLIK, E.: Effect of coloured shade-nets on plant leaf parameters and tomato fruit quality. Journal of the Science of Food and Agriculture, 95, 2660-2667, 2015

ILIĆ S.Z, FALLIK, E. : Light quality manipulation improve vegetables quality at harvest and postharvest: A review. Environmental and Experimental Botany. 139: 79-90, 2017

ILIĆ, S.Z., MILENKOVIĆ, L., ŠUNIĆ, L., FALLIK, E.: Effect of shading by colour nets on plant development, yield and fruit quality of sweet pepper grown under plastic tunnels and open field. Zemdirbyste-Agriculture, 104 (1): 53-62, 2017a

ILIĆ S.Z., MILENKOVIĆ, L., DIMITRIJEVIĆ, A., STANOJEVIĆ, L., CVETKOVIĆ, D., MASTILOVIĆ, J., KEVREŠAN, Ž.: Effect of coloured shade-nets on yield and quality of lettuce (Lactuca sativa L.) during summer production. Scientia Horticulturae. 226: 389-397, 2017b

FALLIK E., ILIĆ Z.: Pre and postharvest treatments affecting flavor quality of fruits and vegetables. p.139-169 In: Siddiqui M.W.(ed), Preharvest modulation of postharvest fruits and vegetables quality. AAP-CRC Press, USA. 2017

KONG,Y., AVRAHAM, L., PERZELAN, Y., ALKALAI-TUVIA, S., RATNER, K., SHAHAK, Y., FALLIK, E.: Pearl netting affects postharvest quality in 'Vergasa' sweet pepper via light environment manipulation. Scientia Horticulturae, 150: 290-298, 2013

KOSMA, C., TRIANTAFYLLIDIS, V., PAPASAVVAS, A., SALAHAS, G., PATAKAS, A.: Yield and nutritional quality of greenhouse lettuce as affected by shading and cultivation season. Emirates Journal of Food and Agriculture 25: 974-979, 2013

LOPEZ, D., CARAZO, N., RODRIGO, M.C., GARCIA, J.: Coloured shade nets effects on tomato crops quality. Acta Horticulturae, 747: 121-124, 2007

MAKLED, A.M.H., ABOLMAATY, S.M., HASSANEIN, M.K., ABD EL-GHAFAR, N.Y.: Impact of type of greenhouse cover sheets on certain major cucumber pests under protected cultivation. New York Science Journal, 5: 19-24, 2012

MASHABELA, M.N., SELAHLE, K.M., SOUNDY, P., CROSBY, K.M., SIVAKUMAR, D.: Bioactive compounds and fruit quality of green sweet pepper grown under different colored shade netting during postharvest storage. Journal of Food Science, 16: 2612-2618, 2015

MILENKOVIĆ, L., ILIĆ, S.Z., ĐUROVKA, M., KAPOULAS, N., MIRECKI, N., FALLIK, E.: Yield and pepper quality as affected by light intensity using color shade nets. Agriculture and Forestry, 58: 19-23, 2012 
MEENA, R.K., VASHISTH, A., SINGH, R., SINGH, B., MANJAIH, K.M.: Study on change in microenvironment under different colour shade nets and its impact on yield of spinach (Spinacia oleracea L.). J. Agrometeorology, 16: 104-111, 2014

MILLER G., SUZUKI, N., YILMAZ, S., MITTLER R.: Reactive oxygen species homeostasis and signalling during drought and salinity stresses. Plant Cell and Environment, 33(4):453-467, 2010

MOLLER, M., ASSOULINE, S.: Effects of a shading screen on microclimate and crop water requirements. Irrigation Science, 25: 171-181, 2007

NTSOANE, M. L.: Effect of photo-selective nettings on plant growth, quality at harvest and after postharvest storage in lettuce varieties. M.S.c. thesis. Dep. Crop Sci. Fac. Sci. Tshwane University of Technology. Pretoria. South Africa, 2015

OMBÓDI, A., PÉK, Z., SZUVANDZSIEV, P., TÓTHNÉ-TASKOVICS, Z., KOHÁZI-KIS, A., KOVÁCS, A., LEDÓNÉ DARÁZSI, H., HELYES, L.: Effects of external coloured shade nets on sweet peppers cultivated in walk-in plastic tunnels. Notulae Botanicae Horti Agrobotanici Cluj-Napoca, 43: 398-403, 2016

PERUCKA, I., OLSZOWKA, K., CHILCZUK, B.: Changes in the chlorophyll content in stored lettuce (Lactuca sativa L.) after pre-harvest foliar application of $\mathrm{CaCl}_{2}$. Acta Agrobotanica, 66: 137-142, 2014

RAJAPAKSE, N.M., SHAHAK Y.: Light quality manipulation by horticulture industry. In: Whitelam, G., Halliday, K. (Eds). Light and plant development. Annual Review of Plant Biology, 30: 290-312, 2007

RIGA, P., ANZA, M., GARBISU, C.: Tomato quality is more dependent on temperature than on photosynthetically active radiation. Journal of the Science of Food and Agriculture, 88:158-166, 2008

SANTANA, J.O., BALBINO, M.A., TAVARES, T.R., BEZERRA, R.S., FARIAS, J.G., FERREIRA, R.C.: Effect of photoselective screens in the development and productivity of red and yellow sweet pepper. Acta Horticulturae, 956: 493-500, 2012

SCHREINER, M.: Phytochemicals in fruit and vegetables: health promotion and postharvest elicitors. Critical Reviews in Plant Sciences, 25: 267-278, 2006

SELAHLE, K.M., SIVAKUMAR, D., JIFON, J., SOUNDY, P.: Postharvest responses of red and yellow sweet peppers grown under photo-selective nets. Food Chemistry, 173: 951-956, 2015

SHAHAK, Y.: Photoselective netting: an overview of the concept, R\&D and practical implementation in agriculture. Acta Horticulturae, 1015: 155-162, 2014

SHAHAK, Y.: Photo-selective netting for improved performance of horticultural crops. A review of ornamental and vegetable studies in Israel. Acta Horticulturae, 770: 161-168, 2008

STAMPS, R.H.: Use of colored shade netting in horticulture. HortScience, 44: 239-241, 2009

TEITEL, M., LIRON, O., HAIM, Y., SEGINER, I.: Flow through inclined and concertina-shape screens. Acta Horticulturae, 801, 99-106, 2008

TINYANE, P.P., SIVAKUMAR, D., VAN ROOYEN, Z.: Influence of photo-selective shade nettings to improve fruit quality at harvest and during postharvest. 'South African avocado growers Association' Yearbook, 38, 2015

Received / Primljen: 01.09.2017. Accepted / Prihvaćen: 18.12.2017. 